\title{
Pengembangan Modul Berbasis Pendekatan Konstruktivisme untuk Memfasilitasi Pemahaman Konsep Matematis Siswa Sekolah Menengah Atas di Pekanbaru
}

\author{
Deby Sarah, Risnawati, Zubaidah Amir MZ \\ Program studi pendidikan matematika, Universitas Islam Negeri Sultan Syarif Kasim Riau \\ e-mail: zubaidah.amir@uin-suska.ac.id
}

\begin{abstract}
ABSTRAK. Penelitian ini didasari oleh kendala yang muncul yaitu belum tersedianya bahan ajar berupa modul yang mampu memfasilitasi pemahaman konsep matematis siswa. Penelitian ini bertujuan untuk menghasilkan modul berbasis pendekatan konstruktivisme yang valid, praktis dan mampu memfasilitasi pemahaman konsep matematis siswa. Jenis penelitian ini adalah penelitian pengembangan (research and development) yang mengacu pada penelitian model ADDIE (Analysis, Design, Development, Implementation, dan Evaluation). Penelitian ini dilakukan di Sekolah Menengah Atas Negeri 6 Pekanbaru. Subjek penelitian ini adalah 6 siswa untuk kelompok kecil dari kelas X MIPA 2 dan 34 siswa untuk kelompok terbatas dari kelas X MIPA 1. Objek penelitian ini adalah modul berbasis pendekatan konstruktivisme. Jenis data berupa data kuantitatif dan data kualitatif. Instrumen pengumpulan data berupa angket uji validitas, angket uji kepraktisan dan soal posttest. Data yang diperoleh kemudian dianalisis dengan teknik analisis deskriptif. Hasil penelitian menunjukkan kualitas modul yang dikembangkan tergolong kategori sangat valid (82\%), dan sangat praktis berdasarkan penilaian dari siswa kelompok kecil $(83 \%)$ dan penilaian dari siswa kelompok terbatas $(82 \%)$, sedangkan pemahaman konsep matematis siswa setelah menggunakan modul berbasis pendekatan konstruktivisme termasuk kategori sangat baik (89, 2). Hasil tersebut mengidentifikasikan bahwa modul berbasis pendekatan konstruktivisme yang dikembangkan telah valid, praktis dan mampu memfasilitasi pemahaman konsep matematis siswa.
\end{abstract}

Kata kunci: Modul, Pendekatan Konstruktivisme, Pemahaman Konsep Matematis.

\section{PENDAHULUAN}

Pembelajaran matematika adalah proses interaksi antara guru dan siswa yang melibatkan pengembangan pola berfikir pada suatu lingkungan belajar yang sengaja diciptakan oleh guru dengan berbagai metode agar program belajar matematika tumbuh dan berkembang secara optimal. Menurut anggapan masyarakat umum dalam Herawati, matematika salah satu pelajaran yang dianggap sulit pada jenjang pendidikan dasar dan menengah. Hal ini karena matematika berhubungan dengan ide-ide dan konsep-konsep abstrak yang saling berkesinambungan dimana dasar komunikasinya dimulai dari unsur-unsur yang tidak terdefinisikan (Herawati, 2010,p. 70). Sementara matematika harus dipahami oleh siswa untuk memenuhi kebutuhan masa kini dan kebutuhan masa datang. Maka dari itu, diperlukan kegiatan pembelajaran matematika yang terancang dengan baik.

Menurut Sumarmo, Tujuan pembelajaran matematika yaitu salah satunya untuk mengenal, memahami, dan menjelaskan keterkaitan antar konsep serta mengaplikasikan konsep, prosedur, prinsip, dan ide atau algoritma secara luwes, akurat, efisien, dan tepat dalam matematika (Sumarmo, 2013,p. 31). Dengan kata lain memahami konsep dalam pembelajaran matematika perlu dimiliki siswa sebagai kemampuan dasar.

Berdasarkan observasi proses kegiatan belajar mengajar dan wawancara bersama guru matematika yang peneliti lakukan di SMAN 6 Pekanbaru, peneliti menemukan bahwa pemahaman konsep matematis siswa dalam memahami matematika masih kurang, sebagian siswa 
belum memahami konsep, belum mampu menjelaskan keterkaitan antar konsep, dan belum mampu mengaplikasikan konsep dengan tepat dalam berbagai pemecahan masalah matematika. Didukung dengan pendapat Trianto dalam Agustina bahwa kenyataan dilapangan siswa hanya menghafal konsep dan kurang mampu menggunakan konsep tersebut jika menemui masalah dalam kehidupan nyata yang berhubungan dengan konsep yang dimiliki (Agustina, 2016, p. 2). Sedangkan Menurut Sutrisno dalam Lasati, permasalahan yang timbul dalam proses belajar mengajar matematika antara lain: pembelajaran konsep dan prosedur dalam matematika yang dipraktekkan di sekolah selama ini membuat siswa hanya menghafalkan rumus atau konsep tanpa memahami maknanya, selama ini guru dipandang sebagai satu-satunya sumber pembelajaran, diperlukan sebuah pendekatan dalam pembelajaran yang dapat menghasilkan output pendidikan berkualitas dan adanya kecenderungan berubahnya pendekatan dalam pembelajaran matematika dari behaviorisme ke konstruktivisme (Lasati, 2007, p 47). Beberapa penelitian menunjukkan bahwa penggunaan model dan strategi pembelaajran dapat meningkatkan kemampuan pemahaman konsep matematis siswa. Peningkatan pemahaman konsep dengan menggunakan model pembelajaran kooperatif tipe kreatif-produktif (Wahidah, Hasanuddin \& Hartono, 2018), Quantum Teaching (Sari, Suhandri \& Nufus, 2018), dan Couse Review Horay (Muhandaz, Trisnawita \& Risnawati, 2018).

Sedangkan ditinjau dari sumber belajar yang digunakan di sekolah, siswa menggunakan buku teks pelajaran (buku paket) dan LKS sebagai sumber belajar. Buku paket matematika tersebut mengandung set-set prosedur yang setiap persoalan membawa kepada satu jawaban yang benar. Sehingga membuat siswa merasa tidak perlu memahami matematika untuk mendapat jawaban yang benar karena mereka hanya perlu menghafal prosedur yang telah diajar dan membuat latihan-latihan yang diberikan tanpa perlu memikirkan mengapa mereka harus menggunakan prosedur tersebut untuk memecahkan masalah. Pandangan seperti ini jika tidak diatasi dapat menyebabkan pelajar menghadapi kesukaran dalam matematika pada peringkat yang lebih tinggi. Dengan kata lain, masih terdapat kekurangan pada sumber belajar yang digunakan di sekolah pada saat ini.

Berdasarkan seluruh permasalahan yang telah dipaparkan, Perbaikan perlu dilakukan. Perbaikan tersebut terletak pada proses pembelajaran dan sumber belajar yang digunakan. Perbaikan pada proses pembelajaran dapat dilakukan dengan menerapkan suatu pendekatan pembelajaran yang tepat agar dapat memfasilitasi pemahaman konsep matematis siswa. Guru perlu menyajikan pendekatan pembelajaran yang dapat melatih siswa untuk membangun sendiri pengetahuannya dalam menemukan konsep. Karena pemahaman konsep sangat dibutuhkan dalam menjalin hubungan dan rangkaian ide yang menerangkan dan memberi makna pada prosedur yang dilakukan. Sehingga konsep pembelajaran akan tertanam berdasarkan pemahamannya sendiri bukan hanya sekedar menghafal. Tindakan menciptakan sesuatu makna dari apa yang dipelajari merupakan pengertian dari pembelajaran konstruktivisme. Maka salah satu alternatif pendekatan yang dapat diterapkan untuk memfasilitasi pemahaman konsep matematis siswa tersebut adalah pendekatan Konstruktivisme.

Menurut Andriani dan Haryani, melalui pendekatan konstruktivisme pengetahuan akan tersusun dan terbangun dalam pikiran siswa sendiri ketika ia berusaha mengorganisasikan pengalaman barunya berdasarkan pada kerangka kognitif yang sudah ada pada pikirannya (Andriani dkk, 2013, p. 34). Di dalam kelas konstruktivisme, para siswa diberdayakan oleh pengetahuan yang berada pada diri mereka sehingga mendorong berkembangnya rasa ingin tahu secara alami pada siswa.

Nurhajati menyatakan dalam teori konstruktivisme, salah satu prinsip yang paling penting dalam psikologi pendidikan adalah bahwa guru tidak hanya sekedar memberikan pengetahuan untuk siswa. Siswa harus membangun sendiri pengetahuan di dalam benaknya (Nurhajati, 2014: 3). Maka dari itu, pembelajaran menggunakan pendekatan Konstruktivisme perlu diterapkan.

Perbaikan selanjutnya yaitu terletak pada sumber belajar. dalam proses belajar mengajar setiap siswa haruslah mempunyai sumber belajar. Salah satu sumber belajar yang dapat digunakan 
oleh siswa yaitu modul. Modul akan memberi kesempatan bagi siswa untuk belajar menurut cara masing-masing, oleh sebab siswa menggunakan teknik yang berbeda-beda untuk memecahkan masalah tertentu berdasarkan latar belakang pengetahuan dan kebiasaan masing-masing. Pengembangan bahan ajar harus memperhatikan tuntutan kurikulum, berarti bahan ajar yang akan kita kembangkan harus sesuai dengan kurikulum yang sedang berlaku.

Modul merupakan suatu unit yang lengkap terdiri dari kegiatan program belajar mengajar yang dapat dipelajari oleh peserta didik dengan bantuan minimal dari guru, meliputi perencanaan tujuan yang akan dicapai secara jelas, penyediaan materi pelajaran, alat yang dibutuhkan dan alat untuk penilai, serta pengukuran keberhasilan peserta didik dalam penyelesaian pelajaran (Prastowo, 2011,p. 104).

Modul yang akan dikembangkan peneliti adalah modul berbasis pendekatan konstruktivisme untuk memfasilitasi pemahaman konsep matematis siswa. Penyajian materi di dalam modul berbasis konstruktivisme mengajak siswa untuk mengeksplorasi pengetahuannya yang sudah ada dengan pengetahuan baru yang diperolehnya sehingga terbentuklah suatu pemahaman konsep yang berasal dari pemikiran mereka sendiri untuk menafsirkan pembelajaran yang mereka pelajari. Modul berbasis pendekatan konstruktivisme menyediakan kegiatan belajar sesuai dengan langkah-langkah pembelajaran konstruktivisme. Dengan kata lain dengan belajar menggunakan modul berbasis pendekatan konstruktivisme maka pemahaman konsep matematis siswa akan terfasilitasi.

Berdasarkan uraian masalah tersebut, peneliti akan melakukan penelitian yang berjudul Pengembangan Modul Berbasis Pendekatan Konstruktivisme Untuk Memfasilitasi Pemahaman Konsep Matematis Siswa Sekolah Menengah Atas di Pekanbaru.

\section{METODE}

Jenis penelitian ini adalah penelitian dan pengembangan (research and development) dengan model pengembangan yang peneliti gunakan ialah model ADDIE. ADDIE adalah singkatan dari analyze, design, development, implementation, dan evaluation. Peneliti memilih model ADDIE karena model ini adalah model yang langkah-langkah desain sistem pembelajarannya relatif sederhana dan mudah dipahami.Subjek dalam penelitian adalah siswa kelas X SMA Negeri 6 Pekanbaru. Sedangkan objek penelitian ini adalah modul matematika berbasis pendekatan konstruktivisme untuk memfasilitasi pemahaman konsep matematis siswa. Waktu penelitian sudah dilaksanakan pada semester ganjil tahun ajaran 2017/2018.

Instrumen yang digunakan dalam penelitian ini adalah lembar validasi instrumen, instrumen validitas dan kepraktisan, tes pemahaman konsep matematis. Teknik analisis data yang digunakan adalah analisis deskriptif kualitatif dan analisis deskriptif kuantitatif.

\section{HASIL DAN PEMBAHASAN}

\section{Uji Validitas}

Uji validitas dilakukan untuk melihat tingkat kevalidan modul yang dikembangkan. Validasi oleh ahli teknologi pendidikan bertujuan untuk melihat kevalidan modul berdasarkan penggunaan huruf dan tulisan modul, desain modul, penggunaan gambar, serta tampilan modul. Validasi oleh ahli materi pembelajaran bertujuan untuk melihat kevalidan modul berdasarkan kualitas isi dan konstruksi modul, kualitas pembelajaran, kualitas interaksi, serta karakteristik modul berdasarkan pendekatan konstruktivisme. Uji validitas dilakukan menggunakan lembar validasi.Berikut adalah hasil validasi secara ringkas. 
Tabel 1. Hasil Validasi Modul Berbasis Pendekatan Konstruktivisme oleh Ahli Teknologi Pendidikan

\begin{tabular}{|l|l|l|l|c|l|}
\hline No. & Variabel Validitas & Indikator & No. Pernyataan & Persentase Keidealan & Kategori \\
\hline \multirow{3}{*}{1} & \multirow{3}{*}{ Syarat Teknis } & A & $1,2,3,4,5$ dan 6 & $83,3 \%$ & Sangat Valid \\
\cline { 3 - 6 } & & B & $7,8,9,10,11,12$ dan 13 & $81 \%$ & Sangat Valid \\
\cline { 3 - 6 } & C & 14,15 dan 16 & $82,2 \%$ & Sangat Valid \\
\cline { 3 - 6 } & D & 17,18 dan 19 & $75,6 \%$ & Valid \\
\cline { 3 - 6 } & \multirow{2}{*}{ E } & 20 & $80 \%$ & Valid \\
\hline \multicolumn{2}{|l|}{ Persentase Keidealan } & & & $\mathbf{8 1} \%$ & Sangat Valid \\
\hline
\end{tabular}

Tabel 2. Hasil Validasi Modul Berbasis Pendekatan Konstruktivisme oleh Ahli Materi Pembelajaran

\begin{tabular}{|c|c|c|c|c|c|}
\hline No & Variabel Validitas & Indikator & No. Pernyataan & $\begin{array}{l}\text { Persentase } \\
\text { Keidealan }\end{array}$ & Kategori \\
\hline \multirow{3}{*}{1} & \multirow{3}{*}{ Syarat Didaktik } & A & $1,2,3$ dan 4 & $81,7 \%$ & Sangat Valid \\
\hline & & $\mathrm{B}$ & 5 dan 6 & $83,3 \%$ & Sangat Valid \\
\hline & & $\mathrm{C}$ & 7,8 dan 9 & $88,9 \%$ & Sangat Valid \\
\hline \multirow{5}{*}{2} & \multirow{5}{*}{ Syarat Konstruksi } & A & 10,11,12 dan 13 & $83,3 \%$ & Sangat Valid \\
\hline & & B & 14,15dan 16 & $80 \%$ & Valid \\
\hline & & $\mathrm{C}$ & 17 & $86,7 \%$ & Sangat Valid \\
\hline & & $\mathrm{D}$ & 18 & $80 \%$ & Valid \\
\hline & & $\mathrm{E}$ & 19 dan 20 & $80 \%$ & Valid \\
\hline 3 & $\begin{array}{l}\text { Syarat Pendekatan } \\
\text { konstruktivisme }\end{array}$ & A & $\begin{array}{l}21,22,23 \\
24 \text { dan } 25\end{array}$ & $82,7 \%$ & Sangat Valid \\
\hline \multicolumn{3}{|c|}{ Persentase Keidealan } & & $82,9 \%$ & Sangat Valid \\
\hline
\end{tabular}

Berdasarkan hasil validasi tersebut, modul matematika memenuhi kriteria sangat valid dengan persentase rata-rata validitas $82 \%$. Ini berarti modulmatematika berbasis pendekatan konstruktivismepada materi SPLTV telah layak digunakan dalam pembelajaran dan dapat digunakan pada uji kepraktisan.

\section{Uji Kepraktisan}

Uji kepraktisan dilakukan setelah proses validasi modul telah selesai dengan minimal berkategori valid. Uji kepraktisan dilakukan untuk mengetahui apakah modul praktis dan mudah digunakan oleh siswa sebagai pengguna. Uji kepraktisan dilakukan terhadap siswa kelas X SMA Negeri 6 Pekanbaru.

\section{Uji Kepraktisan Kelompok Kecil}

Modul yang telah direvisi berdasarkan saran dari validator ahli materi pembelajaran dan validator ahli teknologi pendidikan kemudian diuji cobakan pada kelompok kecil untuk menguji kepraktisan 
modul dan diminta komentar/saran dari siswa sebelum diuji cobakan pada kelompok terbatas. Teknik pengumpulan data yang digunakan adalah angket. Berikut adalah hasil penilaian uji kepraktisan pada kelompok kecil.

Tabel 2. Hasil Uji Kepraktisan Kelompok Kecil

\begin{tabular}{|c|c|c|c|c|c|}
\hline No & $\begin{array}{c}\text { Variabel } \\
\text { Kepraktisan }\end{array}$ & Indikator & $\begin{array}{c}\text { No. } \\
\text { Pernyataan }\end{array}$ & $\begin{array}{c}\text { Persentase } \\
\text { Keidealan }\end{array}$ & Kategori \\
\hline \multirow[t]{2}{*}{1} & \multirow{2}{*}{$\begin{array}{l}\text { Minat Siswa dan } \\
\text { Tampilan Modul }\end{array}$} & A & $\begin{array}{c}1,2,3,4,5,6 \text { dan } \\
7\end{array}$ & $88,1 \%$ & Sangat Praktis \\
\hline & & $\mathrm{B}$ & 8 dan 9 & $81,7 \%$ & Sangat Praktis \\
\hline \multirow[t]{2}{*}{2} & \multirow[t]{2}{*}{ Proses Penggunaan } & A & $\begin{array}{c}10,11,12,13 \\
\text { dan } 14\end{array}$ & $77,3 \%$ & Praktis \\
\hline & & $\mathrm{B}$ & 15 & $80 \%$ & Praktis \\
\hline \multirow{3}{*}{3} & \multirow{3}{*}{$\begin{array}{l}\text { Pendekatan } \\
\text { Konstruktivisme } \\
\text { dan Pemahaman } \\
\text { Konsep }\end{array}$} & A & 16 & $80 \%$ & Praktis \\
\hline & & $\mathrm{B}$ & 17 & $80 \%$ & Praktis \\
\hline & & $\mathrm{C}$ & 18 dan 19 & $85 \%$ & Sangat Praktis \\
\hline 4 & Waktu & A & 20 & $83,3 \%$ & Sangat Praktis \\
\hline 5 & Evaluasi & $\mathrm{A}$ & 21 & $83,3 \%$ & Sangat Praktis \\
\hline \multicolumn{4}{|c|}{ Persentase Keidealan } & $83 \%$ & $\begin{array}{l}\text { Sangat } \\
\text { Praktis }\end{array}$ \\
\hline
\end{tabular}

Berdasarkan tabel tersebut dapat dilihat bahwa persentase keseluruhan dari penilaian siswa dalam uji kepraktisan kelompok kecil adalah sangat praktis, dengan nilai kepraktisan adalah 83\%.

\section{Uji Kepraktisan Kelompok Terbatas}

Uji coba kelompok terbatas dilakukan setelah pengujian modul terhadap kelompok kecil dinilai sangat praktis, kemudian peneliti merevisi modul berdasarkan saran perbaikan dari kelompok kecil. Peneliti melakukan uji coba kelompok terbatas dengan jumlah responden 34 siswa di kelas X MIPA 1 SMAN 6 Pekanbaru. Berikut adalah hasil penilaian uji kepraktisan kelompok terbatas.

Tabel 3. Hasil Uji Kepraktisan Kelompok Terbatas

\begin{tabular}{|c|c|c|c|c|c|}
\hline No & $\begin{array}{l}\text { Variabel } \\
\text { Kepraktisan }\end{array}$ & Indikator & No. Pernyataan & Persentase Keidealan & Kategori \\
\hline \multirow{2}{*}{1} & \multirow{2}{*}{$\begin{array}{l}\text { Minat Siswa dan } \\
\text { Tampilan Modul }\end{array}$} & $\mathrm{A}$ & $1,2,3,4,5,6$ dan 7 & $85,3 \%$ & Sangat Praktis \\
\hline & & $\mathrm{B}$ & 8 dan 9 & $81,2 \%$ & Sangat Praktis \\
\hline \multirow{2}{*}{2} & \multirow{2}{*}{ Proses Penggunaan } & $\mathrm{A}$ & $10,11,12,13$ dan 14 & $79,3 \%$ & Praktis \\
\hline & & $\mathrm{B}$ & 15 & $77,1 \%$ & Praktis \\
\hline \multirow{3}{*}{3} & \multirow{3}{*}{$\begin{array}{l}\text { Pendekatan } \\
\text { Konstruktivisme } \\
\text { dan Pemahaman } \\
\text { Konsep }\end{array}$} & $\mathrm{A}$ & 16 & $80,6 \%$ & Sangat Praktis \\
\hline & & B & 17 & $79,4 \%$ & Praktis \\
\hline & & $\mathrm{C}$ & 18 dan 19 & $82,4 \%$ & Sangat Praktis \\
\hline 4 & Waktu & $\mathrm{A}$ & 20 & $81,2 \%$ & Sangat Praktis \\
\hline 5 & Evaluasi & $\mathrm{A}$ & 21 & $83,5 \%$ & Sangat Praktis \\
\hline \multicolumn{4}{|c|}{ Persentase Keidealan } & $82 \%$ & Sangat Praktis \\
\hline
\end{tabular}

Berdasarkan tabel tersebut dapat dilihat bahwa persentase keseluruhan dari penilaian siswa dalam uji kepraktisan kelompok terbatas adalah sangat praktis, dengan nilai kepraktisan adalah $82 \%$. 


\section{Tes Pemahaman Konsep Matematis}

Posttest dilakukan setelah modul selesai digunakan dalam pembelajaran pada kelompok terbatas dan bertujuan untuk mengetahui apakah semua indikator pencapaian kompetensi telah dikuasai dengan baik oleh siswa atau belum. Pemberian tes dalam penelitian ini digunakan untuk mengetahui sejauh mana pemahaman konsep matematis siswa setelah belajar menggunakan modul berbasis pendekatan konstruktivisme. Dalam penelitian ini subjek penelitiannya adalah siswa kelas X MIPA 1 SMAN 6 Pekanbaru. Soal posttest yang diberikan berupa soal uraian yang berjumlah 7 butir yang sudah divalidasi oleh validator.Berikut ini merupakan hasil posttestpemahaman konsep matematis siswa.

Tabel 4. Hasil Posttest Pemahaman Konsep Matematis Siswa

\begin{tabular}{|c|c|c|c|}
\hline No. & Indikator Pemahaman Konsep Matematis & Tingkat Pemahaman & Kategori \\
\hline 1. & Menyatakan ulang sebuah konsep & 88,8 & Sangat Baik \\
\hline 2. & $\begin{array}{l}\text { Mengklasifikasikan objek menurut sifat-sifat tertentu } \\
\text { (sesuai dengan konsepnya). }\end{array}$ & 93,8 & Sangat Baik \\
\hline 3. & Memberi contoh dan non contoh dari sebuah konsep & 89,7 & Sangat Baik \\
\hline 4. & $\begin{array}{l}\text { Menyajikan konsep dalam berbagai bentuk representasi } \\
\text { matematis }\end{array}$ & 95,6 & Sangat Baik \\
\hline 5. & $\begin{array}{l}\text { Mengembangkan syarat perlu atau syarat cukup dari } \\
\text { suatu konsep }\end{array}$ & 79,4 & Baik \\
\hline 6. & $\begin{array}{l}\text { Menggunakan, memanfaatkan, dan memilih prosedur } \\
\text { atau operasi tertentu }\end{array}$ & 76,5 & Baik \\
\hline 7. & $\begin{array}{l}\text { Mengaplikasikan konsep atau algoritma pemecahan } \\
\text { masalah }\end{array}$ & 82,4 & Baik \\
\hline \multicolumn{2}{|c|}{ Persentase Keidealan Keseluruhan } & 89,2 & Sangat Baik \\
\hline
\end{tabular}

Berdasarkan tabel hasil tes pemahaman konsep matematis siswa tersebut,32 dari 34 siswa telah tuntas dalam pembelajaran.Persentase hasil posttest pemahaman konsepmatematis siswa adalah 89,2\%. Hal ini menunjukkan bahwa modulsudah memfasilitasi pemahaman konsepmatematis dan memberikan manfaat pada proses pembelajaran.

\section{KESIMPULAN}

Berdasarkan hasil perhitungan dan analisis data penelitian yang dilaksanakan di Sekolah Menengah Atas Negeri 6 Pekanbaru mengenai pengembangan modul berbasis pendekatan konstruktivisme untuk memfasilitasi pemahaman konsep matematis siswa, diperoleh beberapa kesimpulan sebagai berikut: 1) Modul matematika berbasis pendekatan konstruktivisme yang dikembangkan telah memenuhi syarat didaktik, syarat konstruksi dan syarat pendekatan konstruktivisme dengan persentase keidealan $82,9 \%$ dan berada pada kategori sangat valid. Modul yang dikembangkan juga telah memenuhi syarat teknis dengan persentase keidealan $81 \%$ dan sudah berada pada kategori sangat valid, sehingga diperoleh rata-rata persentase keidealan secara keseluruhan yaitu $82 \%$ dan sudah termasuk kategori sangat valid. Hal ini menunjukkan bahwa modul yang dikembangkan dapat digunakan sebagai bahan ajar dalam proses pembelajaran matematika. 2) Modul matematika berbasis pendekatan konstruktivisme yang dihasilkan sudah berada pada kategori sangat praktis pada uji coba kelompok kecil dengan persentase 83\%, kemudian modul direvisi dan diuji cobakan ke kelompok terbatas dan hasil uji coba tersebut menyatakan bahwa modul berada pada kategori sangat praktis dengan persentase $82 \%$. Hal ini menunjukkan bahwa modul yang dikembangkan ditinjau dari segi minat siswa dan tampilan modul, proses penggunaan, pendekatan konstruktivisme dan pemahaman konsep, waktu, tingkat kesulitan soal, kemudahan pemakaian dan kemanfaatan bagi siswa sudah sangat praktis. 3) Modul 
matematika berbasis pendekatan konstruktivisme sudah dapat memfasilitasi pemahaman konsep matematis siswa berdasarkan hasil posttest yang dilakukan setelah menggunakan modul dengan rata-rata nilai posttest pemahaman konsep matematis siswa adalah 89,2, sehingga termasuk kategori sangat baik.

Berdasarkan penelitian yang telah dilakukan, peneliti memberikan beberapa saran yang dapat dijadikan dasar dalam pemanfaatan, penggunaan produk, serta melakukan penelitian lebih lanjut. 1) Modul matematika berbasis pendekatan konstruktivisme yang dikembangkan disarankan untuk dapat digunakan sebagai salah satu bahan ajar, karena dinilai sudah sangat valid, sangat praktis, dan mampu memfasilitasi pemahaman konsep matematis siswa sebagai upaya meningkatkan kualitas pembelajaran, khususnya pada materi sistem persamaan linear tiga variabel. 2) Peneliti lain disarankan untuk melakukan pengembangan modul matematika berbasis konstruktivisme dengan menggunakan kelas pembanding dan melakukan uji coba produk pada kelas maupun sekolah yang lain, agar kualitas modul benar-benar teruji dalam hal efektifitasnya. 3) Saat menggunakan modul berbasis pendekatan konstruktivisme hendaknya guru maupun siswa memperhatikan petunjuk penggunaan modul, sehingga pembelajaran akan lebih efektif dan efisien dengan mengikuti langkah-langkah pada modul berbasis pendekatan konstruktivisme. 4) Peneliti menyarankan kepada guru agar penggunaan modul berbasis pendekatan konstruktivisme untuk memfasilitasi pemahaman konsep matematis ini dikolaborasikan dengan metode pembelajaran matematika yang menarik lainnya agar pembelajaran menjadi lebih bervariatif.

\section{REFERENSI}

Agustina, L. (2016). Upaya Meningkatkan Kemampuan Pemahaman Konsep dan Pemecahan Masalah Matematika Siswa SMP Negeri 4 Sipirok Kelas VII Melalui Pendekatan Matematika Realistik (PMR). Jurnal Eksakta. 1(10), 1-7

Andriani, Melly, dan Hariyani, Mimi. (2013). Pembelajaran Matematika. Pekanbaru: Benteng Media.

Badan Standar Nasional Pendidikan. (2006). Model Penilaian Kelas. Jakarta: Depdiknas.

Herawati, O. D. P., Sirof, R., \& Basir D. (2010). Pengaruh Pembelajaran Problem Posing Terhadap Kemampuan Pemahaman Konsep Matematika Siswa Kelas XI IPA SMAN 6 Palembang. Jurnal Pendidikan Matematika, 4(1), 70-80

Lasati, D. (2007). Penerapan Pendekatan Konstruktivisme pada Pembelajaran Teorema Phytagoras di Kelas 8 SMP. Jurnal Pendidikan Inovatif, 3(1), 47-50

Muhandaz, R. Trisnawita, O., \& Risnawati, R. (2018). Pengaruh Model Pembelajaran Course Review Horay terhadap Kemampuan Pemahaman Konsep Matematis Berdasarkan Kemandirian Belajar Siswa SMK Pekanbaru. JURING (Journal for Research in Mathematics Learning), 1(2), 137146

Murizal, A., Yarman, Y., \& Yerizon, Y. (2012). Pemahaman Konsep Matematis dan Model Pembelajaran. Jurnal Pendidikan Matematika, 1(1), 19-23

Nurhajati. (2014). Pengaruh Penerapan Pendekatan Konstruktivisme Dengan Model Pembelajaran Kooperatif Berbantuan Program Cabri 3D Terhadap Kemampuan Penalaran Dan Koneksi Matematis Siswa SMA Di Kota Tasikmalaya. Jurnal Pendidikan dan Keguruan, 1(1), 1-11.

Prastowo, A. (2011). Panduan Kreatif Membuat Bahan Ajar Inovatif. Yogyakarta: Diva Press.

Riyanto, Y. (2009). Paradigma Baru Pembelajaran. Jakarta : kencana.

Sari, R. Suhandri, S. \& Nufus, H. (2018). Pengaruh Penerapan Model Pembelajaran Quantum Teachingterhadap Pemahaman Konsep Matematis Berdasarkan Minat Belajar Matematika Siswa Sekolah Menengah Pertama Kampar. JURING Journal for Research in Mathematics Learning), 1(2), 127-136

Suherman, E. (2001). Evaluasi Pembelajaran Matematika. Bandung: JICA.

Sumarmo, Utari. (2013). Berpikir dan Disposisi Matematik Serta Pembelajarannya. Bandung: FPMIPA-UPI. 
Supraptini. (2015). Peningkatan Prestasi Belajar Matematika Melalui Pendekatan Konstruktivisme pada Siswa Kelas V Semester II SDN 3 Notorejo Kecamatan Gondang Kabupaten Tulungagung Tahun Pelajaran 2012/2013. Jumal Pendidikan Profesional, 4(2), 52-63

Wahidah, N., Hasanuddin, H., Hartono, H. (2018). Pengembangan Lembar Kerja Siswa dengan Model Pembelajaran Koperatif Tipe Kreatif-Produktif untuk Memfasilitasi Kemampuan Pemahaman Konsep Matematis Siswa SMP Negeri 21 Pekanbaru. JURING Journal for Research in Mathematics Learning), 1(1), 79-90

Zakaria, Effandi dkk. (2007). Trend Pengajaran dan Pembelajaran Matematik. Kuala Lumpur: Utusan Publicators and Distributors. 